Article

\title{
Determining Food Security in Crisis Conditions: A Comparative Analysis of the Western Balkans and the EU
}

\author{
Bojan Matkovski *(D), Danilo Đokić (D), Stanislav Zekić and Žana Jurjević (D) \\ Department of Agricultural Economics and Agribusiness, Faculty of Economics in Subotica, \\ University of Novi Sad, 24000 Subotica, Serbia; danilo.djokic@ef.uns.ac.rs (D.Đ.); \\ stanislav.zekic@ef.uns.ac.rs (S.Z.); zana.jurjevic@ef.uns.ac.rs (Ž.J.) \\ * Correspondence: bojan.matkovski@ef.uns.ac.rs; Tel.: +381-24628049
}

Received: 2 November 2020; Accepted: 25 November 2020; Published: 27 November 2020

\begin{abstract}
The right to food is a fundamental one, and the optimization between human needs and available resources is a challenge in all countries. The main goal of this study is to find the factors that determine food security and to determine the level of food security in the Western Balkans while undergoing the process of European Union (EU) integration. In order to achieve this, four Food and Agricultural Organization (FAO) dimensions of food security are analyzed: stability, availability, access, and utilization. The Preference Ranking Organization Method for Enrichment Evaluations (PROMETHEE) method is then used to rank Western Balkan and EU countries according to food security. The results show a significant difference among these countries in terms of their levels of food security, which is a consequence of Western Balkan countries' significant lag in economic development in comparison to the EU. Although the level of food security in Western Balkan countries is lower than in EU countries, it is not endangered. However, it can become endangered under crisis conditions (like the COVID-19 pandemic). The main reasons for this discrepancy are high food supply variability, dependence on cereal import, and lower Gross Domestic Product (GDP) per capita in these countries than in EU.
\end{abstract}

Keywords: food security; Western Balkan; EU; PROMETHEE; COVID-19

\section{Introduction}

The concept of food security has been developing for over 40 years. This term was first used at the World Food Conference in 1974, when the focus was on food availability and price stability. Definition of food security was created under the influence of the crisis that was present at the beginning of the seventies of the 20th century as "availability at all times of adequate world food supplies of basic foodstuffs to sustain a steady expansion of food consumption and to offset fluctuations in production and prices". In 1983, the FAO expanded the definition of food security in the area of access to food for certain vulnerable groups. Food security should "ensure that the entire population at all times has a physical and economic approach to the basic food products they need". In the 1986 World Bank Report on Poverty and Hunger the concept of food security includes malnutrition, poverty, and specific topics of food security: "Access to enough food for all people, at all times, for an active, healthy life" [1]. Additionally, national food security was used by some to mean self-sufficiency, i.e., the country produces the food it needs or that which its population demands [2]. The most widely accepted definition of food security was created at the World Food Summit in 1996, where "food security at the individual, household, state, regional and world level is achieved when all people have a physical and economic approach at all times with sufficient amounts of safe and adequate 
food to satisfy their needs and different preferences for active and healthy life". At the World Food Summit of 2009, it was concluded that the concept of food security includes four dimensions: stability, accessibility, access, and use (Figure 1) [3].

Stability as a dimension of food security refers to people's ability to have access to available food at all times. It relates both to the aspect of supply and to the aspect of demand within food security. The second dimension of food security refers to the availability of food: the availability of sufficient quantities of adequate food quality, either from domestic production or from imports. This dimension does not only include physical availability, it also involves nutritional characteristics of food. The third dimension of food security, access to food, covers the demand side of food security. It answers the question of whether people have enough resources to afford adequate and healthy food. This dimension implies both economic and physical access to food. The last dimension of food security refers to the use of food. It consists of two parts; the first part refers to indicators that reflect children's nourishment under 5 years of age, while the second part relates to quality and hygiene conditions [4]. Increased food consumption does not necessarily mean improving the food security of the country. It is essential to increase the use of high-quality food that will contribute to the health of the population. One of the essential instruments for providing global food security is trade because trade policies can positively influence food security [5]. Liberalization of trade can redirect production in areas with more convenient resources, lead to higher income levels, and boost economic growth and income growth per capita.

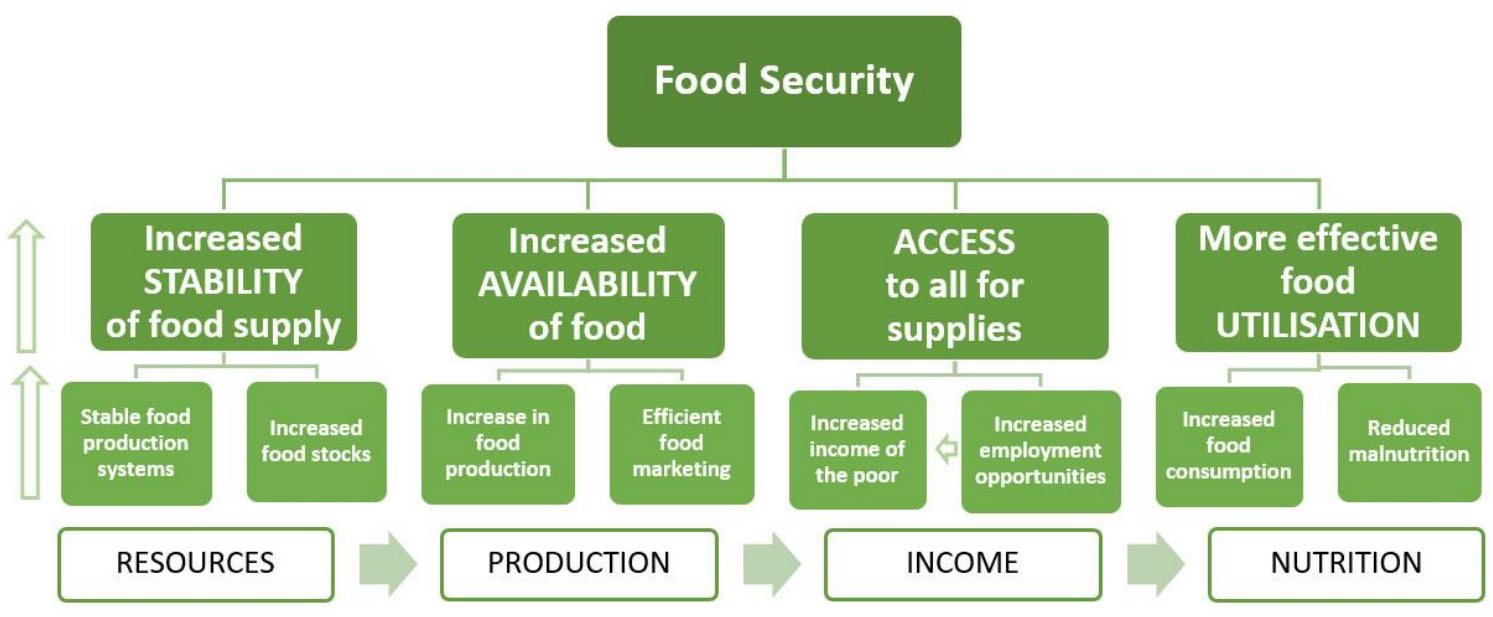

Figure 1. Dimensions of food security. Source: http://www.fao.org/3/y5898e07.htm [6].

One of the crucial questions is whether there is enough food available for the world's population. The most recent analysis [7] showed that before the COVID-19 pandemic, in 2019, almost 690 million people ( $8.9 \%$ of the global population) were undernourished. The same analysis showed a negative trend and projections that the number of undernourished people would exceed 840 million by 2030, so the world is not on track to achieve zero hunger. Some studies indicate that agricultural production would still need to increase by $70 \%$ (nearly 100\% in developing countries) by 2050 to cope with a $40 \%$ increase in the world population and raise average food consumption to $3130 \mathrm{kcal}$ per person day [8]. On the other hand, some studies showed that there was already enough food in 2012 to feed 10 billion people (the world's 2050 projected population peak) [9]. However, the number of undernourished people worldwide has been on the rise since 2014, after a prolonged decline. There are many reasons why food security is not adequate, such as poverty, population growth, natural cataclysms, and armed conflicts [10]. There is a threat to food production due to global changes in weather and climate, especially in countries in the southern hemisphere which are not the main originators of climate change. They may suffer the greatest share of damage in the form of declining yields and greater frequency of extreme weather events [11]. As the world's population increases, issues of food security become more pressing, as does the need to sustain soil fertility and minimize its degradation [12]. Additionally, 
food production problems, such as plant pathology accrued in industrialized and developing countries, endanger food security [13]. Some additional causes do not have such a huge impact. For example, even gender, family, and decision-making power play a critical role in interacting with culture, and its impact on food security and food security policy could be improved by taking culture better into account [14]. Of course, all factors that affect food security should be included in the process of policy creation, but with a different priority. Improving the level of food security is an important policy goal, and it could be done in different ways: increasing world food supply, improving access to food, and rising consumer food purchasing power [15]. Agricultural and food production systems play an essential role in increasing the world food supply. An improved outlook on agriculture's main issues and the food system, founded on the strong evidence base, can lead to accelerated progress in achieving global food security, nutrition, and other development goals [16]. However, all these ways of reducing food insecurity are not so relevant in crisis conditions.

As the countries of the Western Balkans are in the process of integrating into the European Union (EU), the liberalization process is carried out, so changes in the level of food security are very important. Western Balkan countries are countries on the Balkan Peninsula, which were part of Yugoslavia (Serbia, Bosnia and Herzegovina, North Macedonia, Montenegro, and Croatia), as well as Albania. These countries are in a different status in the process of integration to the EU; Croatia has been a full member since 2013. However, Croatia was part of Yugoslavia, so it is very interesting as a benchmark, as the only member state of the EU from the Western Balkans. Namely, since the last decade, significant changes have occurred in Western Balkan countries due to adjustment to the international market; market opportunities have been changing, primarily because of the reduced trade barriers with the EU and the regional countries [17]. Integration of Western Balkan countries in Central European Free Trade Agreement (CEFTA) had significantly intensive foreign trade of agri-food products, while Stabilization and Association Agreement with EU had limited effects on trade of these products [18], primarily because of unfavorable export opportunities of the majority of Western Balkan countries on EU market. The economic and political prospect of these countries, as well as their future within the EU, is one of the important priorities in the EU. Economies of the countries of the Western Balkans are already closely related to the EU; the EU is their most important trading partner, the largest source of foreign direct investment and other financial resources, as well as the primary destination for external migration [19]. The EU membership process is slower in the Western Balkan countries than it was in Central and Eastern Europe, a consequence of the numerous economic and political problems inherited from the past. Except for Croatia, which is a full member of EU, Serbia, as well as Montenegro, moved the most in the negotiation process. Experience in the countries of Central and Eastern Europe shows that there have been significant changes in prices, production, and trade in agri-food products, both in the period after the EU accession, as well as in the preaccession period. The extent to which these changes will occur depends primarily on the policies of individual countries, on market adaptation, and on the ability to find a market where agri-food products are competitive [20]. These countries have also influenced various crises: permanent political instability, the migrant crisis, and the new COVID-19 pandemic crisis in 2020. Mentioned changes and adjustments to crisis conditions could cause significant changes in food security levels, so the main objective of this paper is to find the factors that determine food security, as well as to determine the level of food security in Western Balkan within the process of EU integration. Additionally, the influence of the crisis on level of food security will be determined.

The paper is organized as follows: after the introduction has been elaborated, a literature review of the theoretical basis of food security is presented. The research methodology used in this paper is described in the third section and the fourth section includes presentation of results, followed by discussion. The conclusion includes implications of the results as well as consideration of food security of Western Balkan countries in EU accession process. 


\section{Literature Review}

Numerous authors have examined the levels of food security of different regions using food security dimensions. The general conclusion is that there is enough food in the world for the entire population $[5,9,21]$. However, according to Jambor and Babu (2017) [5], food availability does not always guarantee a high food security level. Developed countries with high levels of income, low variability of food prices on the domestic market, and adequate infrastructure have good access to food. Contrary to this, developing countries with low levels of income, high variability in food prices, and poorly developed roads have serious problems regarding food access. Additionally, the population of developed countries has a better energy supply structure of nutrition, as well as access to better sources of water and sanitation than is the case of developing countries. Generally, the developing country has poorer stability measured by foreign trade in the food trade, food price changes, and food supply indicators. It can be concluded that highly developed countries are nutritionally safe, while food security is confronted with many challenges in developing countries, where lower income is achieved. Additionally, developing countries are more endangered in a crisis condition, such as the pandemic of COVID-19. Namely, COVID-19 is expected to worsen global food security, and preliminary projections suggest that the pandemic may add between 83 and 132 million people to the total number of undernourished in the world in 2020, depending on the economic growth scenario [7].

In the Western Balkans region, there are scarce researches when it comes to food security. In a paper authored by Brankov and Lovre (2017), it analyzed food security in the former Yugoslavia countries using FAO food security indicators, and the results pointed to significant differences between the analyzed countries [22]. This study also suggested a need to solve the complex interrelationships between these countries to ensure food security. In addition, authors Papic Brankov and Milovanović (2015) analyzed food security in Serbia using a set of indicators. Results showed that the greatest negative impact on the food system has a low level of gross domestic product per capita, as well as corruption [23]. In this regard, numerous measures have been proposed to improve Serbia's food security, emphasizing the adoption of adequate food standards and strategies, the establishment of trust with investors, and the reduction of corruption present in the agri-food sector. Recent research of food security issues in the former Yugoslavia countries authored by Kovljenić and Raletić-Jotanović (2020) [24] showed a significant influence of the different factors on the level of food security: level of economic development, population growth, foreign trade, investments in agriculture. This study also showed that of all countries of the former Yugoslavia, Slovenia is the most food secure country, while the lowest level of food security is held by Bosnia and Herzegovina. The Global Food Security Index (GFSI) analyzes and ranks countries for food security, but out of the 113 countries included in the ranking, only Serbia is analyzed from the Western Balkans. According to the results for 2019, Serbia was ranked as the 59th country (out of 113), and the main dangers of achieving adequate food security were highlighted: low level of gross domestic product per capita, low budget allocation for public expenditure in agriculture, corruption, and nutritional standards [25].

\section{Materials and Methods}

Due to the low inclusion of the Western Balkan countries in the framework of the GFSI, for the analysis of food security in these countries, as well as the comparison with the EU countries, the FAO set of indicators of food security was used. The method of multicriteria decision making was used in the Preference Ranking Organization Method for Enrichment Evaluations (PROMETHEE), which was defined by the authors Brans, Mareschal, and Vincka (1984) [26]. This method successfully addresses the problems of multicriteria ranking based on a number of criteria often presented to different units, usually of varying significance and with different needs for minimizing or maximizing. The PROMETHEE method's input is a matrix consisting of a set of potential alternatives $\mathrm{A}$, where each element in A has its own $\mathrm{f}(\mathrm{a})$, which represents the criterion evaluation. There are two ways of ranking: the alternative partial ranking method-PROMETHEE I-and the full ranking method of alternatives-PROMETHEE II. PROMETHEE I represent the partial ranking method. 
PROMETHEE calculates positive and negative flows of preferences for every alternative. The positive flow shows how one alternative dominates over the others, while the negative flow shows their weaknesses compared to the other alternatives. The positive flow can be presented:

$$
\varphi^{+}(a)=\frac{1}{n-1} \sum_{b \in A} \pi(a, b)
$$

While a negative flow can be presented:

$$
\varphi^{-}(a)=\frac{1}{n-1} \sum_{b \in A} \pi(a, b)
$$

where

$\varphi^{+}(a)$-represents the positive flow;

$\varphi^{-}(a)$-represents the negative flow;

$n$-represents numbers of alternatives;

$A$-represents a set of potential alternatives A;

$a$-represents observed alternative;

$b$-represents other alternatives that belong to A;

$\pi$-represents a multicriteria preference degree.

In order to eliminate partial relations, the PROMETHEE II method, which combines the ranking of alternatives for a net flow, is developed as follows: $\varphi(a)=\varphi^{+}(a)-\varphi^{-}(a)$.

After that, the PROMETHEE method calculates the net flow $\varphi(\mathrm{P})$ as the difference between these two flows [26]. When ranking alternatives according to all criteria, it is recommended to use both methods. Namely, it is much easier to use the complete ranking method, but the analysis of incomparable alternatives often helps to arrive at an adequate conclusion. Analysis of multicriteria decision-making for country ranking according to the level of food security was done using Visual PROMETHEE software.

For the analysis of food security in the countries of the Western Balkans and the EU, FAO indicators of food security were used, for which data existed for all countries. Due to problems with the availability of data from the analysis, some indicators were excluded. The main reason some indicators were excluded from the analysis is that there are no data for most countries' observed period in the Western Balkans. These are mainly indicators related to nutrition and health of children under the age of five (e.g., \% age of children under 5 years affected by wasting, \% age of children under 5 years of age who are overweight, the prevalence of exclusive breastfeeding among infants $0-5$ months of age, the prevalence of exclusive breastfeeding among infants 0-5 months of age, the prevalence of low birthweight). Therefore, the analysis included 15 indicators that were within the scope of different dimensions of food security:

\section{STABILITY}

- Cereal import dependency ratio (percent)

- Per capita food supply variability (kcal/cap/day)

- Percent of arable land equipped for irrigation (percent)

- Political stability and absence of violence/terrorism (index)

- Value of food imports in total merchandise exports (percent)

2. AVAILABILITY

- Average dietary energy supply adequacy (percent)

- Average protein supply (g/cap/day) 
- Average supply of protein of animal origin (g/cap/day)

3. ACCESS

- Gross domestic product per capita, PPP, dissemination (constant 2011 international dollars)

- Prevalence of moderate or severe food insecurity in the total population (percent)

- Prevalence of severe food insecurity in the total population (percent)

4. UTILISATION

- Percentage of population using safely managed drinking water services (percent)

- Percentage of population using safely managed sanitation services (percent)

- Prevalence of anemia among women of reproductive age (15-49 years)

- Prevalence of obesity in the adult population (18 years and older)

An empirical basis for food security indicators was completed using the FAO database [27]. Each indicator was given an adequate criterion (minimum or maximum) to see the overall effect of all indicators on food security. This analysis included all Western Balkan countries and EU countries (except Cyprus and Luxembourg), over 5 years (average for period 2016-2020). In order to better understand indicators, a descriptive statistic for all analyzed countries is presented in Table A1.

After ranking Western Balkan and EU countries according to food security, a model for identifying key factors influencing food security was developed and estimated. Namely, four explanatory variables are selected as the representatives of production and foreign trade performances of agriculture as the main factors determining agricultural and food production potentials, so factors that influence food security level the most.

$$
X_{i}=\alpha+\beta_{1} G P_{i}+\beta_{2} A_{P R}+\beta_{3} E P_{i}+\beta_{4} L_{A N D}+u_{i t}
$$

where:

$\mathrm{X}_{\mathrm{i}}$-represents the level of food security in the country $\mathrm{i}$;

$\mathrm{GDP}_{\mathrm{i}}$-represents the share of the added value of agriculture in GDP in the country $\mathrm{i}$;

$\mathrm{APR}_{\mathrm{i}}$ - represents the value of agricultural production per capita in the country $\mathrm{i}$;

EXP $_{\mathrm{i}}$-represents the share of export of agricultural products in total export in the country $\mathrm{i}$;

$\mathrm{LAND}_{\mathrm{i}}$-represents land productivity in the country $\mathrm{i}$;

$\mathrm{u}_{\mathrm{i}}$-random error of the model.

The expected influence of explanatory variables on the dependent variable is defined in Table 1. Namely, as indicators of economic relevance of agriculture in one country, the share of value-added in agriculture in GDP and the export of agricultural products in total export negatively influence the level of food security. Additionally, it was expected that the value of agricultural production per capita and land productivity positively influences the level of food security. Calculations of agricultural production per capita, the share of agricultural export in total export, and land productivity were made using data from FAO database [27], while data on value added in agriculture (\% of GDP) came from the World Bank database [28]. For an empirical confirmation of the significance of considered factors, an adequate form of regression models was used for 31 countries from Western Balkans and the EU (same countries as in previous analysis on PROMETHEE ranking of countries according to food security). Descriptive statistics for all independent variables is presented in Table A2. 
Table 1. Explanatory variables.

\begin{tabular}{cccc}
\hline Variable & Description & Source & Expected Relationship \\
\hline $\mathrm{GDP}_{\mathrm{i}}$ & $\begin{array}{c}\text { Value added in agriculture (\% of GDP) } \\
\text { Agricultural production in USD per } \\
\text { capita }\end{array}$ & World Bank & negative \\
$\mathrm{APR}_{\mathrm{i}}$ & $\begin{array}{c}\text { Share of export of agricultural } \\
\text { products in total export }\end{array}$ & FAO & positive \\
$\mathrm{EXP}_{\mathrm{i}}$ & Land productivity in USD per hectare & FAO & negative \\
$\mathrm{LAND}_{\mathrm{i}}$ & positive \\
\hline
\end{tabular}

Source: the authors' composition.

\section{Results}

Table 2 shows the results of the ranking of the countries of the Western Balkans and the EU according to food security, while Figure 2 clearly shows the classification of analyzed countries according to food security levels into three groups: countries with higher, medium, and lower levels of food security.

Table 2. Ranking of Western Balkan and EU countries according to food security.

\begin{tabular}{|c|c|c|c|c|c|c|c|}
\hline Rank & Country & $\begin{array}{c}\text { Food } \\
\text { Security }\end{array}$ & Stability & Availability & Access & Utilization & \\
\hline 1. & Austria & 0.4978 & 0.4067 & 0.5111 & 0.6222 & 0.5083 & \multirow{11}{*}{ 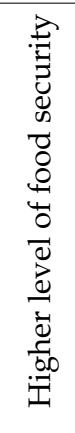 } \\
\hline 2. & Germany & 0.4222 & 0.2333 & 0.2222 & 0.8222 & 0.5083 & \\
\hline 3. & Denmark & 0.4111 & 0.3067 & 0.4444 & 0.5222 & 0.4333 & \\
\hline 4. & Finland & 0.3911 & 0.3000 & 0.6000 & 0.0333 & 0.6167 & \\
\hline 5. & Netherlands & 0.3756 & 0.2333 & 0.0222 & 0.4778 & 0.7417 & \\
\hline 6. & Sweden & 0.3489 & 0.4600 & 0.1111 & 0.4556 & 0.3083 & \\
\hline 7. & France & 0.2933 & 0.1467 & 0.7111 & 0.3778 & 0.1000 & \\
\hline 8. & Malta & 0.2578 & 0.1333 & 0.4667 & 0.4222 & 0.1333 & \\
\hline 9. & Italy & 0.1800 & 0.0333 & 0.1889 & 0.2222 & 0.3250 & \\
\hline 10. & Ireland & 0.1467 & -0.0333 & 0.6444 & 0.2000 & -0.0417 & \\
\hline 11. & Spain & 0.1044 & 0.0067 & 0.1333 & 0.1000 & 0.2083 & \\
\hline 12. & Estonia & 0.1022 & 0.1533 & -0.0556 & 0.1778 & 0.1000 & \multirow{11}{*}{ 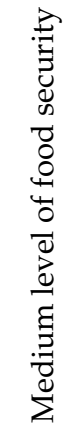 } \\
\hline 13. & Portugal & 0.0867 & 0.0600 & 0.7222 & -0.4667 & 0.0583 & \\
\hline 14. & Poland & 0.0600 & 0.0000 & -0.0111 & 0.4000 & -0.0667 & \\
\hline 15. & Belgium & 0.0578 & -0.2333 & 0.2000 & -0.2000 & 0.5083 & \\
\hline 16. & Czechia & 0.0444 & 0.2200 & -0.5556 & 0.6889 & -0.2083 & \\
\hline 17. & Slovenia & 0.0356 & 0.2467 & -0.3667 & 0.1778 & -0.0333 & \\
\hline 18. & Lithuania & 0.0289 & 0.0867 & 0.7889 & -0.2444 & -0.4083 & \\
\hline 19. & United Kingdom & 0.0267 & -0.4400 & 0.0222 & 0.2000 & 0.4833 & \\
\hline 20. & Slovakia & -0.0400 & 0.2000 & -0.9556 & 0.3778 & 0.0333 & \\
\hline 21. & Greece & -0.1333 & -0.2000 & -0.0778 & -0.6444 & 0.2917 & \\
\hline 22. & Hungary & -0.1667 & 0.2000 & -0.6222 & 0.0222 & -0.4250 & \\
\hline 23. & Latvia & -0.1756 & -0.1333 & -0.4111 & 0.0444 & -0.2167 & \multirow{9}{*}{ 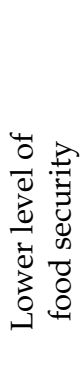 } \\
\hline 24. & Romania & -0.2800 & -0.0267 & 0.1889 & -0.7778 & -0.5750 & \\
\hline 25. & Montenegro & -0.3378 & -0.6267 & 0.4556 & -0.6111 & -0.3667 & \\
\hline 26. & Croatia & -0.3667 & -0.1867 & -0.6444 & 0.0000 & -0.6583 & \\
\hline 27. & Albania & -0.3756 & -0.4000 & 0.3778 & -1.000 & -0.4417 & \\
\hline 28. & Bulgaria & -0.4489 & -0.1200 & -0.8000 & -0.6111 & -0.4750 & \\
\hline 29. & Serbia & -0.4622 & -0.0467 & -0.8667 & -0.6000 & -0.5750 & \\
\hline 30. & North Macedonia & -0.5200 & -0.1800 & -0.9111 & -0.8000 & -0.4417 & \\
\hline 31. & $\begin{array}{l}\text { Bosnia and } \\
\text { Herzegovina }\end{array}$ & -0.5644 & -0.8000 & -0.5333 & -0.3889 & -0.4250 & \\
\hline
\end{tabular}

Source: the authors' calculations.

The best ranked country is Austria, followed by the most developed countries in the EU: Germany, Denmark, Finland, Netherlands, and Sweden. In the first group of countries of higher level of food 
security are also France, Malta, Italy, and Ireland. It can be noticed that the majority of countries with a higher level of food security has consisted of $4 \mathrm{EU}$ founders and the countries of Scandinavia, so the first group has the relatively most developed EU countries. All of these countries are highly ranked within the GFSI ranking, so these countries are among the top 25 in food security in the world in 2019 [25].

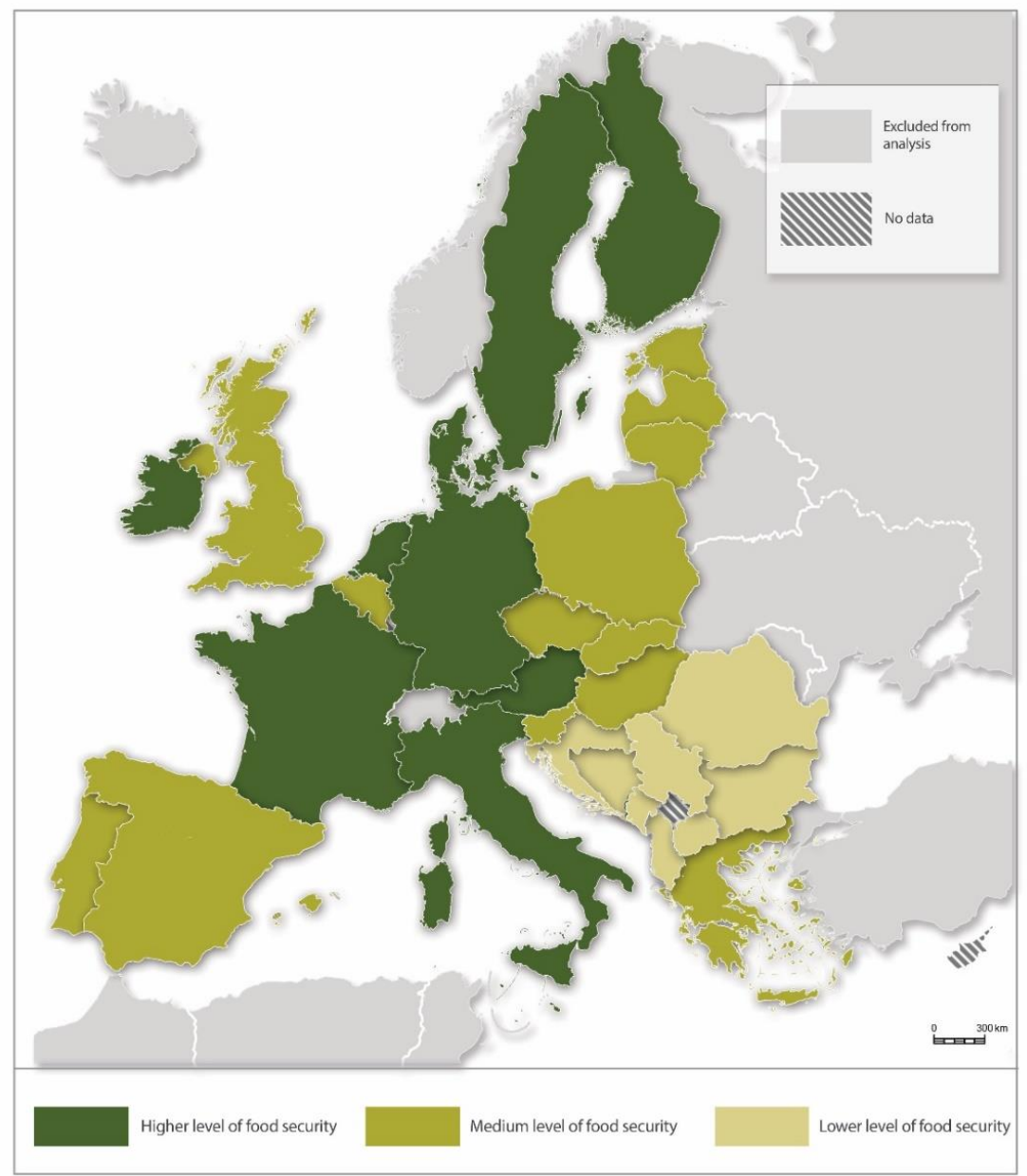

Figure 2. Food security in Western Balkans and EU countries. Source: the authors' illustration.

The next group of countries with a medium level of food security is: Spain, Estonia, Portugal, Poland, Belgium, Czechia, Slovenia, Lithuania, United Kingdom, Slovakia, Greece, Hungary, and Latvia. The good results of this group of countries in terms of the level of food security are also a consequence of their better economic development, as well as earlier accession to the EU. Most of these countries are well ranked by the GFSI ranking [25].

The third group consists of all countries of the Western Balkans (red color in Table 2) and Romania and Bulgaria. Romania is the best ranked in the third group, followed by Montenegro. The worst countries for food security are North Macedonia and Bosnia and Herzegovina. As these countries are the weakest economically and least progressed in terms of joining the EU, it can be concluded that economic development, among other factors, has a significant impact on the level of food security of the country.

Clusters of EU and Western Balkan countries according to dimensions of food security are shown in Figure 3. The stability of food supply is lower in the Western Balkans than in the EU, especially in Albania, Montenegro, and Bosnia and Herzegovina. In all three countries there is a large per capita food supply variability (Bosnia and Herzegovina 84\%, Montenegro 86\%, Albania 155\%), while the average for the entire sample is $43 \%$. In addition, Montenegro has a high dependence on cereal imports 
(93\%), while Bosnia and Herzegovina has the highest level of political instability. In total, four Western Balkan countries (North Macedonia, Serbia, Croatia, and Bosnia and Herzegovina) are among the worst ranked when it comes to food availability. However, average dietary energy supply adequacy is at satisfactory level (more than $110 \%$ ) although it is beyond sample average. The average protein supply varies between $80 \mathrm{~g}$ and $96 \mathrm{~g}$. The main reason why food access is lower in the Western Balkans is the low level of GDP per capita. In these countries, the average GDP per capita is approximately 18,000 international dollars, while the EU average is 41,000 international dollars. Food utilization i a problem in the entire Western Balkan. Most worrying is that prevalence of anemia among women of reproductive age is $25 \%$. Additionally, the \% age of the population using safely managed sanitation services is less than $60 \%$ (only $17 \%$ in North Macedonia), while the EU average is $90 \%$.

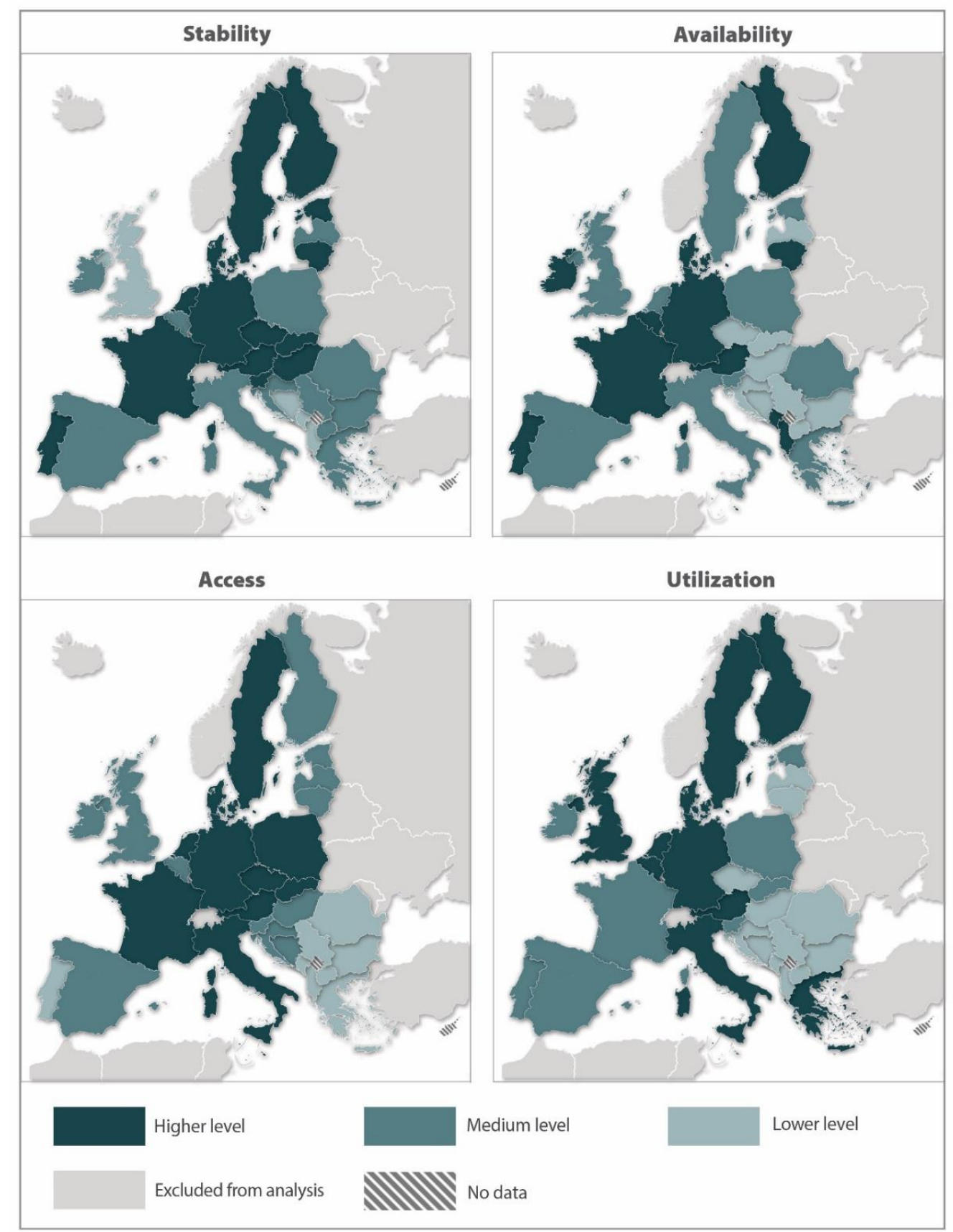

Figure 3. Dimensions of food security in Western Balkans and EU countries. Source: the authors' illustration. 
According to the results of the estimated ordinary least squares (OLS) model (Table 3), all variables are statistically significant, and all variables have expected signs of the regression coefficient. The estimated model explains $67.88 \%$ of explanatory variables variations. Validation of the model is presented by $\mathrm{F}$ results and by the statistically significant impact of all variables on the dependent variable $(p<0.05$ for all variables, except land productivity, where is $p<0.1)$. All basic prerequisites in econometric modeling are involved in the model, so based on Table 3 , the model is well designed for optimal econometric estimation.

Table 3. Model estimation—ordinary least squares (OLS). (Dependent variable level of food security).

\begin{tabular}{ccccc}
\hline Variable & Coefficient & Std. Error & t-Ratio & $p$-Value \\
\hline const & 0.1154900 & 0.1050900 & 1.0990 & 0.2819 \\
\hline$G D P_{i}$ & -0.0395801 & 0.0096626 & -4.0962 & 0.0004 \\
\hline$A P R_{i}$ & 0.0005480 & 0.0001878 & 2.9173 & 0.0072 \\
\hline$E X P_{i}$ & -2.7961000 & 0.7581260 & -3.6882 & 0.0010 \\
\hline$L A N D_{i}$ & 0.0000384 & 0.0000213 & 1.7968 & 0.0840 \\
\hline Mean dependent var & 0.000000 & S.D. dependent var & 0.305939 \\
\hline Sum squared resid & 0.901949 & S.E. of regression & 0.186253 \\
\hline R-squared & 0.678788 & Adjusted R-squared & 0.629371 \\
\hline F (4, 26) & 13.73587 & $p$-value (F) & 0.000003 \\
\hline Log-likelihood & 10.83927 & Akaike criterion & -11.67854 \\
\hline Schwarz criterion & -4.508606 & Hannan-Quinn & -9.341321 \\
\hline Source: the authors' calculations.
\end{tabular}

In the estimated model, the significance of value-added in agriculture in GDP and the export of agricultural products in total export have a significant and negative impact on the level of food security. It is expected because developed countries relatively have a lower contribution of agriculture in GDP, as well as lower contribution in total export, so these variables are indicators of overall economic development. More economically developed countries have achieved much better food security levels, which is also shown by PROMETHEE ranking of countries according to food security levels. Agricultural production per capita and land productivity have a significant and positive effect on the level of food security. These results clearly show that production performances, which can be derived from these two factors, significantly influence food security levels.

\section{Discussion}

The results of a comparative analysis of food security indicate an obvious gap between the countries of the Western Balkans and the EU, but there is also a distinction between the EU countries themselves. Generally speaking, all analyzed countries are nutritionally safe; however, there is a clear difference between the Western Balkans and the EU countries. This difference is conditioned by the resource structure that differs significantly [29], but also by different policies in this area [30], significantly lower levels of state support to agriculture, as well as the negative foreign trade balance of agricultural and food products in all countries of the Western Balkans, except for Serbia [31].

Three indicators are particularly important for food security of the Western Balkans: food supply variability, dependence on cereal import and GDP per capita. Each of these indicators are additionally important in cases of crisis. There are several possible scenarios (Table 4) based on current crises as well as crises from the recent past. 
Table 4. Possible scenarios based on current crisis and policy recommendations.

\begin{tabular}{|c|c|c|c|}
\hline Scenario & Cause & Potential Consequences & Policy Recommendation \\
\hline $\begin{array}{l}\text { Food price increase } \\
\text { and income decline }\end{array}$ & COVID-19 & $\begin{array}{c}\text { Food supply chains disruption } \\
\text { High food prices } \\
\text { The massive job losses } \\
\text { Income decline } \\
\text { Questionable quality of nutrition }\end{array}$ & \multirow{4}{*}{$\begin{array}{c}\text { Strengthening } \\
\text { self-sufficiency in food } \\
\text { production by a consistent } \\
\text { agricultural policy } \\
\text { Create an agricultural policy } \\
\text { that support the } \\
\text { improvement of agricultural } \\
\text { productivity } \\
\text { Strengthening regional } \\
\text { cooperation } \\
\text { Accelerate the EU } \\
\text { accession process }\end{array}$} \\
\hline Export restrictions & COVID-19 & $\begin{array}{l}\text { Food shortages in some Western } \\
\text { Balkan countries } \\
\text { High food prices in some Western } \\
\text { Balkan countries } \\
\text { Questionable quality of nutrition }\end{array}$ & \\
\hline $\begin{array}{l}\text { Trade distractions in } \\
\text { Western Balkans }\end{array}$ & $\begin{array}{l}\text { Unstable political } \\
\text { situation in the } \\
\text { Western Balkans }\end{array}$ & $\begin{array}{c}\text { Food shortages in some Western } \\
\text { Balkan countries }\end{array}$ & \\
\hline $\begin{array}{l}\text { The migrant crisis and } \\
\text { political situation in } \\
\text { the region }\end{array}$ & Migrant crisis & $\begin{array}{c}\text { Additional political destabilization } \\
\text { of the region that may have } \\
\text { consequences for trade and food } \\
\text { availability }\end{array}$ & \\
\hline
\end{tabular}

Source: the authors' illustration.

One possible scenario is related to a coronavirus pandemic and a possible rise in food prices and income decline. The COVID-19 is a health crisis with multiple and widespread impacts on food systems, social systems, and economic development [32]. There are currently more than 56 million infected with COVID-19, and this virus has caused 1.3 million deaths so far [33]. It is difficult to predict what the final outcome of this pandemic will be. As agriculture is concerned, crisis effects are multiple because they can influence supply, demand, labor, food security, food safety, and trade [34]. This crisis has highlighted the importance of agri-food products, which have become a staple in all countries that have endured a period of lockdown [35]. This crisis affects food security in several ways. First, food supply chains are disrupted due to lockdown measures and illnesses among food system workers. Second, the global recession has resulted in massive job losses. Third, a number of compounding factors have contributed to highly uneven food price dynamics at both local and global scales [36]. Food supply chains in the Western Balkans are characterized by a low level of integration, which often affects the inability to provide adequate supply for local and regional distribution systems because products are not competitive, neither in terms of quality nor in terms of price [37]. The COVID-19 pandemic highlighted problems supply chains face in Western Balkan countries because in this crisis situation, they showed inflexibility and inability to meet the sudden market demand for basic foodstuffs on time [38]. Although not all other effects are visible yet, the reduced food supply will certainly cause a rise in price that would put additional pressure on the household budget. According to the most recent research [39], the pandemic of COVID-19 has had a unique impact on all dimensions of the customer retail experience which is the most pronounced in availability and prices. As mentioned, the countries of the Western Balkans are at a lower level of development than the EU (GDP per capita vary between 13,000 international dollars and 27,000 international dollars in Western Balkan countries, while the average for EU is about 41,000 international dollars), and average household income is lower. It can get worse if massive job losses occur in this region. In the structure of household consumption, the share of consumption for food and beverages is still significant (for example, in Serbia, it is about $30 \%$ ), and any increase in food prices or income decrease has a more significant impact on the welfare of society than is the case in developed countries. Reducing the amount of food, as well as lower incomes, can also have an impact on the availability of quality food. One of the symbols of healthy and highly nutritious food is organic food. Although there is a growing demand for these products across Europe [40], the crisis may force the population to choose cheaper and lower quality food, especially in less developed regions such as the Western Balkans. In addition to the negative effect on human health, this can have consequences for organic food producers' business, leading to a serious slowdown in the development of the organic products market. Additionally, great attention must be paid to food 
safety because quality became element with new values in a multidimensional approach of economy consumption primarily as the globalization of economic and social life has highlighted the need for a unitary approach on how to produce quality and safe products for the final consumer [41].

Another possible scenario is for certain countries to impose export restrictions. Fortunately, only Kazakhstan (which has a 3\% share in global wheat exports) has announced export restrictions among the biggest food exporters. Additionally, Russia is reportedly considering a ban on wheat exports [42]. Certainly, if this crisis continues, there is a threat that other countries will impose export restrictions, which would force some Western Balkan countries to rely on their own resources. This can lead the countries of the Western Balkans into a potential problem with food security. The large variability of food supply per capita, which is especially characteristic of Albania, Bosnia and Herzegovina, and Montenegro, indicates that the food market is quite unstable. Potential food shortages resulting from reduced international trade caused by crises can have significant consequences for food availability. Additionally, there is a possibility of regional trade distraction due to the unstable political situation in the Western Balkans. Historically, the Western Balkans countries have gone through the "transitional crisis" common to all former socialist countries after war events. The war conflicts on the former Yugoslavia territory lasted for almost the entire last decade of the 20th century. Political stabilization and significant economic growth were not noticeable until the early 2000s. The EU has not been able to reproduce its success story from the Central and Eastern European (CEE) enlargement in the Western Balkans where governance effectiveness has increased under the influence of EU conditionality, but the level of democracy in the region is stagnating at best [43]. However, unresolved political issues are still present. There have been several examples of implementing high import taxes in this region in the past 10 years. Any restriction on regional trade is a problem for countries with a high level of dependence on food imports.

Additionally, the region is also on a very frequent migrant route. Certainly, the migrant crisis has the potential to destabilize this region in the future. Although cooperation was good during the 2015-16 refugee crisis [19], there is no guarantee that such a relationship will continue in the future.

In order to achieve self-sufficiency in food production, agriculture is of special importance. Although most of these countries have relatively favorable agri-environmental conditions for agricultural production, agricultural development lags significantly behind EU countries (especially EU-12). One of the reasons is that agriculture in almost all of the Western Balkans is characterized by extensive production (high share of crop production) [44]. Such a production structure causes a high dependence on weather conditions and relatively high variability of production. Therefore, net exports, which are present only in Serbia, are based on the export of raw materials. The structure of agricultural farms is also not favorable $[31,44,45]$. There is a large share of small farms characterized by low income and a low degree of capital accumulation. Some countries, such as Bosnia and Herzegovina and Montenegro, have a strong import dependence when it comes to basic food items, such as cereals. Except for Croatia, the Western Balkans are not part of the EU, and are not able to use funds from the Common Agricultural Policy (CAP). The national agricultural policies are mainly aimed at solving social problems in agriculture. In the process of EU integration, all Western Balkan countries must modify their agricultural policy measures to enable an economically and politically acceptable, as well as administratively feasible, shift to the CAP on the day of accession [30]. In addition to the desirable harmonization of national agricultural policies with the CAP model, the Western Balkans countries should focus on improving production performance and increasing competitiveness during the preaccession period of their national agricultural policy. Although there are tendencies towards greater support for the modernization and growth of the agricultural sector's competitiveness, this is far below the European level. Apart from budget constraints, the problem is also in the ad hoc approach and the lack of a long-term strategy for developing the agricultural sector. Thus, key aspects of integrating Western Balkan countries to the EU that push these countries to adapt their agricultural policies to the CAP are the accession negotiation pressures and EU IPARD support [46]. 
This paper's results are in line with results in previous research on this issue [22-24]. The research results showed significant differences among analyzed countries in terms of food security levels [22] and, as the main indicator of discrepancy stands out GDP per capita $[23,24]$. Thus, the creation of adequate strategies and policies is necessary to increase food security [24]. In that context, this research's main policy implications are the defined factors that influence food security in Western Balkan countries. This research provides a useful review of food security and determines which factors are crucial for the food security in Western Balkan countries compared with EU countries. It is essential for policymakers to identify what determinants should be improved, especially in case of a crisis, such as the pandemic of COVID-19. This research's main limitation is the impossibility of empirical estimation influence of crisis condition's (COVID-19) on the level of food security, as there are no estimates of this yet. Due to this, it will be the subject of our future researches.

\section{Conclusions}

Since there are a limited number of papers analyzing Western Balkan and EU countries' food security, this paper contributes to filling this literature gap. The framework is also conceptually innovative in ranking the countries according to food security using the FAO dimensions of food security. Concerning all limitations of the study, conclusions can be summarized as follows:

- All analyzed countries are nutritionally secure, although some Western Balkan countries are highly dependent on imports of agri-food products, but the modern retail sector allows imports from relatively developed countries of the region and the EU. Such a foreign trade balance is not a threat to food security, it is a troubling indicator of the underdeveloped sector as well problems in the supply chain itself. In that context, in crisis cases where foreign trade flows are disturbed, food security in Western Balkan countries could be more endangered, primarily because of its export dependency (except in Serbia) and underdeveloped supply chain.

- Comparative analysis of food security indicates an obvious gap between the countries of the Western Balkans and the EU, but there is also a distinction between the EU countries themselves;

- Economic development, among other factors, has a significant impact on the level of food security of the country, which puts the countries of the Western Balkans in a worse position than the EU countries;

- Differences in agricultural structure, state support to agriculture, and level of integration of supply chains create gap between food security of Western Balkan and EU. Due to this, research results of this paper could be very useful for policymakers because this research has defined the factors influencing food security in Western Balkan and EU countries the most.

- The extensive structure of agricultural production, as well as the presence of small family farms, and the present rural poverty, is a significant constraint in the further development of agricultural production in the Western Balkans;

- The countries of the Western Balkans, except Croatia, are not part of the EU food system, i.e., they do not have an adequate level of support for the agricultural sector in relation to the EU member states;

- The lower level of development characterizes supply chains in the Western Balkans, so the main challenges in improving supply chains are reflected in lowering transaction costs and improving product quality through innovation and investing in new technologies.

- The lower level of food security in the Western Balkans countries compared to the EU can become a problem in crisis conditions, such as political instability, the migrant crisis, and the state of the pandemic. This is particularly pronounced in countries with high food supply variability, dependence on cereal imports, and lower GDP per capita.

- Based on the current COVID-19 pandemic crisis, there are a few possible scenarios considering food security. Namely, this crisis as an effect has a potential rise in food prices and income decline, disruption of food supply chains, global recession, and export restrictions. Thus, this research is 
essential for policymakers to identify factors that should be taken into account to maintain and improve food security.

Comparing European and other countries on food security levels and determining key factors that affect food security will be the focus for future papers. Additionally, empirical modelling of the influence of crisis condition (COVID-19) on the level of food security will be conducted.

Author Contributions: Conceptualization, B.M. and S.Z.; methodology and investigation, D.Đ. and B.M.; writing—original draft preparation, review, and editing, B.M., D.Đ., S.Z., and Ž.J.; visualization, Ž.J.; supervision, B.M. All authors have read and agreed to the published version of the manuscript.

Funding: This research received no external funding.

Conflicts of Interest: The authors declare no conflict of interest.

\section{Appendix A}

Table A1. Descriptive statistic for indicators of food security in Western Balkans and EU countries.

\begin{tabular}{|c|c|c|c|c|c|}
\hline Indicators & Average & $\begin{array}{l}\text { Standard } \\
\text { Deviation }\end{array}$ & $\begin{array}{l}\text { Coefficient of } \\
\text { Variation in \% }\end{array}$ & Minimum & Maximum \\
\hline Cereal import dependency ratio (percent) & -23.53 & 87.95 & -3.74 & -229.40 & 93.50 \\
\hline Per capita food supply variability (kcal/cap/day) & 43.94 & 30.30 & 0.69 & 14.00 & 155.00 \\
\hline $\begin{array}{l}\text { Percent of arable land equipped for irrigation } \\
\text { (percent) }\end{array}$ & 18.09 & 22.06 & 1.22 & 0.10 & 71.20 \\
\hline $\begin{array}{l}\text { Political stability and absence of violence/terrorism } \\
\text { (index) }\end{array}$ & 0.55 & 0.41 & 0.74 & -0.38 & 1.20 \\
\hline $\begin{array}{l}\text { Value of food imports in total merchandise exports } \\
\text { (percent) }\end{array}$ & 12.00 & 18.68 & 1.56 & 4.00 & 109.00 \\
\hline Average dietary energy supply adequacy (percent) & 131.77 & 10.09 & 0.08 & 108.00 & 150.00 \\
\hline Average protein supply (g/cap/day) & 101.34 & 12.84 & 0.13 & 64.70 & 125.00 \\
\hline $\begin{array}{l}\text { Average supply of protein of animal origin } \\
\text { (g/cap/day) }\end{array}$ & 57.30 & 11.77 & 0.21 & 32.30 & 74.30 \\
\hline $\begin{array}{l}\text { Gross domestic product per capita, PPP, } \\
\text { dissemination (constant } 2011 \text { international \$) }\end{array}$ & 37187.19 & 15078.81 & 0.41 & 13287.00 & 80353.00 \\
\hline $\begin{array}{l}\text { Prevalence of moderate or severe food insecurity in } \\
\text { the total population (percent) }\end{array}$ & 9.51 & 6.31 & 0.66 & 3.63 & 38.23 \\
\hline $\begin{array}{l}\text { Prevalence of severe food insecurity in the total } \\
\text { population (percent) }\end{array}$ & 1.92 & 1.87 & 0.97 & 0.50 & 10.50 \\
\hline $\begin{array}{l}\text { Percentage of population using safely managed } \\
\text { drinking water services (percent) }\end{array}$ & 94.21 & 7.65 & 0.08 & 70.00 & 100.00 \\
\hline $\begin{array}{l}\text { Percentage of population using safely managed } \\
\text { sanitation services (percent) }\end{array}$ & 80.89 & 24.30 & 0.30 & 16.60 & 99.20 \\
\hline $\begin{array}{l}\text { Prevalence of anaemia among women of } \\
\text { reproductive age (15-49 years) }\end{array}$ & 21.02 & 5.60 & 0.27 & 6.10 & 29.40 \\
\hline $\begin{array}{l}\text { Prevalence of obesity in the adult population (18 } \\
\text { years and older) }\end{array}$ & 22.78 & 2.59 & 0.11 & 17.90 & 28.90 \\
\hline
\end{tabular}

Source: the authors' calculations.

Table A2. Descriptive statistic for variables for model estimation.

\begin{tabular}{lcccc}
\hline \multicolumn{1}{c}{ Indicators } & Average & $\begin{array}{c}\text { Standard } \\
\text { Deviation }\end{array}$ & $\begin{array}{c}\text { Coefficient of } \\
\text { Variation in \% }\end{array}$ & Minimum \\
\hline Malue added in agriculture (\% of GDP) & 3.41 & 3.70 & 1.08 & 0.60 \\
Agricultural production in USD per capita & 473.43 & 209.34 & 0.44 & 153.06 \\
$\begin{array}{l}\text { Share of export of agricultural products in total } \\
\text { export }\end{array}$ & 10.71 & 5.17 & 0.48 & 1045.81 \\
Land productivity in USD per hectare & 1547.58 & 1666.33 & 1.08 & 3.19 \\
\hline
\end{tabular}

Source: the authors' calculations.

\section{References}

1. World Bank. Available online: https://openknowledge.worldbank.org/handle/10986/5970 (accessed on 18 November 2020).

2. Pinstrup-Andersen, P. Food security: Definition and measurement. Food Secur. 2009, 1, 5-7. [CrossRef]

3. FAO. Available online: http://www.fao.org/3/a-y4671e.pdf (accessed on 22 October 2020). 
4. FAO. Available online: http://www.fao.org/3/a-i3434e.pdf (accessed on 22 October 2020).

5. Jambor, A.; Babu, S. Competitiveness of Global Agriculture; Springer International Publishing: Cham, Switzerland, 2016.

6. FAO. Available online: http://www.fao.org/3/y5898e07.htm (accessed on 22 October 2020).

7. FAO; IFAD; UNICEF; WFP; WHO. Available online: http://www.fao.org/documents/card/en/c/ca9692en/ (accessed on 18 November 2020).

8. Bruinsma, J. The Resource Outlook to 2050: By how much do land, water and crop yields need to increase by 2050 ? How to Feed the World in 2050. In Proceedings of a Technical Meeting of Experts, Rome, Italy, 24-26 June 2009; pp. 1-33.

9. Holt-Giménez, E.; Shattuck, A.; Altieri, M.; Herren, H.; Gliessman, S. We already grow enough food for 10 billion people ... and still can't end hunger. J. Sustain. Agric. 2012, 36, 595-598. [CrossRef]

10. Prosekov, A.Y.; Ivanova, S.A. Food security: The challenge of the present. Geoforum 2018, 91,73-77. [CrossRef]

11. Tripathi, A.D.; Mishra, R.; Maurya, K.K.; Singh, R.B.; Wilson, D.W. Estimates for world population and global food availability for global health. In The Role of Functional Food Security in Global Health; Academic Press: Cambridge, MA, USA, 2019; pp. 3-24.

12. Oliver, M.A.; Gregory, P.J. Soil, food security and human health: A review. Eur. J. Soil Sci. 2015, 66, 257-276. [CrossRef]

13. Strange, R.N.; Scott, P.R. Plant disease: A threat to global food security. Annu. Rev. Phytopathol 2005, 43, 83-116. [CrossRef] [PubMed]

14. Alonso, E.B.; Cockx, L.; Swinnen, J. Culture and food security. Glob. Food Secur. 2018, 17, 113-127. [CrossRef]

15. Chavas, J.P. On food security and the economic valuation of food. Food Policy 2017, 69, 58-67. [CrossRef]

16. Fan, S.; Brzeska, J. Sustainable food security and nutrition: Demystifying conventional beliefs. Glob. Food Secur. 2016, 11, 11-16. [CrossRef]

17. Matkovski, B.; Zekić, S.; Savić, M.; Radovanov, B. Trade of agri-food products in the EU enlargement process: Evidence from the Southeastern Europe. Agric. Econ. Czech 2018, 64, 357-366.

18. Matkovski, B.; Radovanov, B.; Zekić, S. The Effects of Foreign Agri-food Trade Liberalization in South East Europe. Ekon. Cas. 2018, 66, 945-966.

19. Dabrowski, M.; Myachenkova, Y. The Western Balkans on the road to the European Union. Bruegel Policy Contrib. 2018, 4.

20. Mizik, T.; Meyers, W. The possible effects of the EU accession on the Western Balkans agricultural trade. Econ. Agric. 2013, 60, 857-865.

21. Latham, J.R. There's enough food for everyone, but the poor can't afford to buy it. Nature 2000, 404, 222. [CrossRef]

22. Brankov, T.; Lovre, I. Food security in the Former Yugoslav Republics. Econ. Agric. 2017, 64, 701-721. [CrossRef]

23. Papić Brankov, T.; Milovanović, M. Measuring food security in the Republic of Serbia. Econ. Agric. 2015, 62, 801-812. [CrossRef]

24. Kovljenić, M.; Raletić-Jotanović, S. Food security issues in the former Yugoslav countries. Outlook Agric. 2020. [CrossRef]

25. Global Food Security Index (GFSI). Available online: https://foodsecurityindex.eiu.com/ (accessed on 21 October 2020).

26. Brans, J.; Mareschal, B.; Vincke, P. PROMETHEE: A New Family of Outranking Methods in Multicriteria Analysis; Universite Libre de Bruxelles: Bruxelles, Belgium, 1984.

27. FAO. Available online: http://faostat.fao.org/ (accessed on 7 October 2020).

28. World Bank. Available online: https://data.worldbank.org/ (accessed on 9 October 2020).

29. Gajić, M.; Matkovski, B.; Zekić, S.; Đokić, D. Development performances of agriculture in the Danube region countries. Econ. Agric. 2015, 62, 921-936.

30. Volk, T.; Rednak, M.; Erjavec, E.; Rac, I.; Zhllima, E.; Gjeci, G.; Bajramović, S.; Vaško, Ž.; Kerolli-Mustafa, M.; Gjokaj, E.; et al. Agricultural Policy Developments and EU Approximation process in the Western Balkan Countries; Ilic, B., Pavloska-Gjorgjieska, D., Ciaian, P., Eds.; Publications Office of the European Union: Luxembourg, 2019.

31. Volk, T.; Rednak, M.; Erjavec, E. Cross Country Analysis of agriculture and Agricultural Policy of Southeastern European Countries in Comparison with the European Union. In Agricultural Policy and European Integration 
in Southeastern Europe; Volk, T., Erjavec, E., Mortensen, K., Eds.; Food and Agriculture Organization of the United Nations: Budapest, Hungary, 2014; pp. 9-38.

32. Swinnen, J.; McDermott, J. COVID-19: Assessing Impacts and Policy Responses for Food and Nutrition Security; International Food Policy Research Institute: Washington, DC, USA, 2020.

33. Worldometers. Available online: https://www.worldometers.info/coronavirus/? (accessed on 18 November 2020).

34. Jámbor, A.; Czine, P.; Balogh, P. The Impact of the Coronavirus on Agriculture: First Evidence Based on Global Newspapers. Sustainability 2020, 12, 4535. [CrossRef]

35. Borsellino, V.; Kaliji, S.A.; Schimmenti, E. COVID-19 Drives Consumer Behaviour and Agro-Food Markets towards Healthier and More Sustainable Patterns. Sustainability 2020, 12, 8366. [CrossRef]

36. Clapp, J.; Moseley, W.G. This food crisis is different: COVID-19 and the fragility of the neoliberal food security order. J. Peasant Stud. 2020, 1-25. [CrossRef]

37. Erjavec, E.; Mortensen, K.; Volk, T.; Rednak, M.; Eberlin, R.; Ludvig, K. Gap analysis and recommendations. In Agricultural Policy and European Integration in Southeastern Europe; Erjavec, E., Volk, T., Mortense, K.N., Eds.; Food and Agriculture Organization of the United Nations: Budapest, Hungary, 2014; pp. 39-60.

38. Končar, J.; Grubor, A.; Marić, R.; Vučenović, S.; Vukmirović, G. Setbacks to IoT implementation in the function of FMCG supply chain sustainability during COVID-19 pandemic. Sustainability 2020, 12, 7391. [CrossRef]

39. Leone, L.A.; Fleischhacker, S.; Anderson-Steeves, B.; Harper, K.; Winkler, M.; Racine, E.; Baquero, B.; Gittelsohn, J. Healthy Food Retail during the COVID-19 Pandemic: Challenges and Future Directions. Int. J. Environ. Res. Public Health 2020, 17, 7397. [CrossRef] [PubMed]

40. Končar, J.; Grubor, A.; Marić, R. Improving the placement of food products of organic origin on the AP Vojvodina market. Strateg. Manag. 2019, 24, 24-32. [CrossRef]

41. Pop, S.Z.; Dracea, R.; Vlădulescu, C. Comparative Study of Certification Schemes for Food Safety Management Systems in the European Union Context. Amfiteatru Econ. 2018, 20, 9-29. [CrossRef]

42. Glauber, J.; Laborde, D.; Martin, W.; Vos, R. COVID-19: Trade restrictions are worst possible response to safeguard food security. In COVID-19 \& Global Food Security; International Food Policy Research Institute: Washington, DC, USA, 2020.

43. Richter, S.; Wunsch, N. Money, power, glory: The linkages between EU conditionality and state capture in the Western Balkans. J. Eur. Public Policy 2020, 27, 41-62. [CrossRef]

44. Bogdanov, N.; Rodić, V.; Vittuari, M. Structural change and transition in the agricultural sector: Experience of Serbia. Communist Post-Communist Stud. 2017, 50, 319-330. [CrossRef]

45. Lovre, K. Technical change in agricultural development of the Western Balkan countries. In 152nd EAAE Seminar-Emerging Technologies and the Development of Agriculture (1-14); Tomić, D., Lovre, K., Subić, J., Ševarlić, M., Eds.; Serbian Association of Agricultural Economists, Faculty of Economics in Subotica, Institute of Agricultural Economics: Novi Sad, Serbia, 2016.

46. Erjavec, E.; Volk, T.; Rednak, M.; Ciaian, P.; Lazdinis, M. Agricultural policies and European Union accession processes in the Western Balkans: Aspirations versus reality. Eurasian Geogr. Econ. 2020, 1-30. [CrossRef]

Publisher's Note: MDPI stays neutral with regard to jurisdictional claims in published maps and institutional affiliations.

(C) 2020 by the authors. Licensee MDPI, Basel, Switzerland. This article is an open access article distributed under the terms and conditions of the Creative Commons Attribution (CC BY) license (http://creativecommons.org/licenses/by/4.0/). 